\section{Mariusz CISZEK}

Instytut Nauk Spolecznych Akademii Podlaskiej w Siedlcach

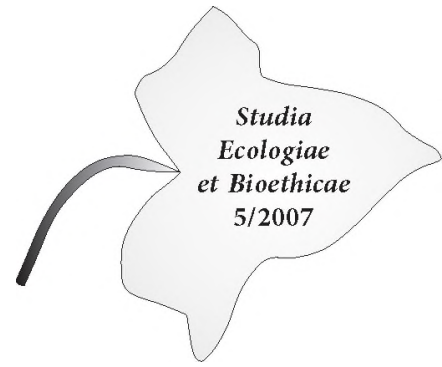

\title{
The Idea of Theocentrism in The Catholic Environmental Ethics
}

The theocentric version of ecological ethics orders to consider any relations between the moral actions of a man and the nature in relation to God as the Creator of nature and cosmos. Nature is valuable because of God who created it and keeps it in its being. The man as the special being should serve as a good guard, host and patron of the world of nature that was given to him as a gift from the Creator. By destroying the nature we defy God and, therefore, we commit sins and do wrong.

\section{Introduction}

The title of my article is: "The idea of theocentrism in the catholic environmental ethics." It is an interdisciplinary thesis because it touches upon the issues of philosophy, ethics, theology and ecology.

For many years I have been interested in ecology, both in its natural aspect and also humanistic. Observing the world around, I have come to the conclusion that the natural world that surrounds us has been destroyed to a large extent by the human being and it has a bad influence on the life and health of the inhabitants of the planet. I do think, however, that even the best laws concerning environmental protection will not be effective if people refuse to value and respect the nature, thus treating it as a value. It is environmental (ecological) ethics that is concerned with this issue because it treats nature as a moral value and, therefore, its unjustified destruction is regarded as morally evil. The theoretical assumptions devised by this science are to create basis for practical actions connected with pro-ecological education. I hope that my considerations contained in this article will convince the reader that nature should be respected as it is intrinsically valuable and one should take care of nature. This way we will improve the state of the protection of our nature, which will also beneficially influence our health. 
The main thought of my article concentrates on the idea of theocentrism and in the catholic environmental (ecological) ethics. Before I describe the title issue, first I would like to refer to other streams contained in environmental (ecological) ethics. As I have mentioned before, environmental ethics treats the world as a moral value that should be taken care of. However, amongst ethicians there are many discrepancies as to the place in value hierarchy that the nature should take. These discrepancies caused there being two mainstreams in environmental ethics that are named anthropocentrism and biocentrism.

\section{The Anthropocentric and Biocentric Model for Enviromental Ethics}

The anthropocentric environmental ethics (anthropocentrism) is a concept that places the human being in the centre of all the things that exist, thus assuming that moral commitments refer only to the people. Of course, the nature (and also animal species) should also be protected, but only because of the fact that by protecting nature we protect people. In such assumption nature has only instrumental, practical value, it serves as a valuable collection of natural resources that should be protected from exploiting. The man is the lord of the nature.

The biocentric kind of environmental ethics (biocentrism) presents opposite point of view. It postulates that the man is only a part of biosphere and for that reason it does not deserve any special position. For biocentrists the nature is an autothelic value, a supreme value, for this reason it is a value in itself. The nature is, therefore, an ordered system, ruled by its own laws, the world of the men is only one of many links of the whole. Nature can exist without the man, but a man cannot exist without the nature. Therefore, the traditional species domination should yield to the principle of equality and cooperation.

Of course, such position is unacceptable for Christians as it questions the essence of traditional theology of creation and the phenomenon of the man. In my opinion, criticising anthropocentrism is in many points unjustified. Personally I am inclined to allocate, within the analysed issue of anthropocentrism two subdomains: extreme and moderate. Anthropocentrism in its moderate version is unavoidable as ethics is intrinsically anthropocentric, because only people can differentiate between good and evil. It is true that the man destroyed the environment, however, it is only the man who could repair this state of things.

For the current ecological crisis the people who are in favour of biocentrism blame the anthropocentric ethics. They think that this traditional attitude of the man towards the nature viewed from the position of the master of all creation who draws from natural resources caused in effect the global ecological crisis. Moreover, they also think that it is the anthropocentric Judeo-Christian tradition 
that should be blamed for the existing ecological crisis. Biocentrists refer to excerpts from the Bible that say that the man should make the earth its own. Deflecting these charges injurious to Christianity has also made me touch upon this subject.

\section{The Theocentrical Model for The Catholic Enviromental Ethics}

I think that the Bible contains many fragments that emphasise the exceptional value of nature, it is in the Genesis when God, after creating the whole world thought of it as good. This assumption is the nucleus of my article, where I have tried to prove that environmental ethics based on the authority of Christianity has many pro-ecological merits, therefore, one should not cite biblical excerpts out of context. From the point of view of Christian moral theology the acts of immoderate using of nature's resources are immoral because they are a derivative of consumptive lifestyle putting emphasis only to material side of human existence, totally omitting the spiritual level. Such extreme attitude is skewed and non-Christian. Only on this basis one could defy claims that Christian tradition is not ecological.

The catholic ethicians pay attention to the fact that the anthropocentrism of the Old Testament is relative and moderate because it is the theocentric and not homocentric vision of the world that is important. It is God that is in the centre as the Lord and Creator of all living, and not the man who cannot aspire to be divine. Such shift of the accent has a very important influence on the basis of the modern Christian ecological ethics. More and more often it is emphasised that the appropriate paradigm for it should be the theocentric model and not the anthropocentric one.

That is why I decided to present my own, author concept of the catholic version of ecological ethics. I think that ecological ethics in theocentric paradigm can be a kind third way that can avoid controversies that two antagonistic advocates of diverse extreme attitudes of biocentrism and anthropocentrism faced. In my opinion the theocentric model can avoid these extremities that is why it is an effective way of practising ecological ethics.

In brief, the theocentric version of ecological ethics orders to consider any relations between the moral actions of a man and the nature in relation to God as the Creator of nature and cosmos. Nature is valuable because of God who created it and keeps it in its being. The man as the special being should serve as a good guard, host and patron of the world of nature that was given to him as a gift from the Creator. By destroying the nature we defy God and, therefore, we commit sins and do wrong. 
I think we should concentrate more on this thought. As it is known the supreme good in the catholic ethics is God. He also is the summum bonum in my theocentric concept of the Christian Environmental Ethics. It is God who created man and nature, which is constantly kept in being, however it is only the man that was created in God's image, after His likeness and was given a spiritual element. The natural environment is the gift of God, that man should take care and respect and keep in appropriate balance. The autethelic, supreme value in my concept of catholic ecological ethics is man, actually his dignity being a moral standard, which should be respected, which also conditions the necessity of keeping his health and life, being the aim in itself. In fact, from the point of view of thomistic anthropology it is the non-destroyed natural environment that is the instrumental value, which means it is the means to achieve a greater aim (supreme value), because without it one cannot stay healthy and it is impossible to preserve human life. In such approach the necessity of demanding respect for a man is also the basis of the respect for the natural environment. One should not forget that the value of the natural environment in the light of the theology of creation definitely exceeds utilitarian solutions as the nature "in its whole is characterised by special value that means that it is the reflection of the God Himself. The beauty of nature is the reflection of God's dignity. The reflection that one should respect, preserve and protect," the difference being that the value of the nature is of less importance that the value of a person, of a man. Never will we accomplish the supreme aim (supreme value) if we do not change our own lifestyle. That is why it is essential that ecological conscience be shaped and also dispositions for action, moral skills, namely virtues that in a sense are peculiar values - means leading us to achieve balance in natural environment that guarantees a dignified preserving of human life and health. These values - means are prudence and moderation and the braces that combines them both is love without which there can be nothing good in the world.

\section{Conclusion}

On the basis of the above considerations one should assume that the man as a being comprising "the crown of the creation" is especially responsible for the whole surrounding natural world, which should be respected as it is the gift from the Creator for the man and should be kept as heritage to future generations, naturally with the use of education. 


\section{Literature}

BoŁoz W., Bibline podstawy ekoteologii, in: Ochrona środowiska spoleczno-przyrodniczego w filozofii i teologii, (ed.): J.M. Dołęga, J.W. Czartoszewski, A. Skowroński, Warszawa 2001.

CiszeK M., Antropocentryczne czy teocentryczne podstawy chrześcijańskiej etyki środowiskowej?, in: Etyka środowiskowa wyzwaniem XXI wieku (ed.): J.W. Czartoszewski, Warszawa 2002.

Ciszer M., Antropoprioryczna koncepcja chrześcijańskiej etyki środowiskowej oraz jej implikacje w bezpieczeństwie ekologicznym, in: Ekofilozofia, bioetyka, etyka biznesu. Aktualne problemy wspótczesności, (ed.): J. Jaron, Siedlce 2004.

CIszeK M., Ekologiczne aspekty aretologii jako fundament polityki oraz gospodarki trwałego i zrównoważonego rozwoju (ekorozwoju), in: Problemy XXI wieku. Prawo ochrony środowiska, edukacja środowiskowa i agrobiznes, (ed.): J.W. Czartoszewski, E. Grzegorzewicz, A.W. Świderski, Warszawa 2005.

Ciszer M., Ekologiczne aspekty katolickiej teologii moralnej, „Studia Ecologiae et Bioethicae”. Recensio Internationalis, 2/2004, Warszawa 2005.

CIszer M., Etyka środowiskowa (ekologiczna) jako nowa dziedzina etyki na podstawie polskiej literatury przedmiotu, in: Filozofia polska w okresie transformacji ustrojowej, (ed.): W. Słomski, Siedlce 2003.

Ciszeк M., Filozoficzne modele realizowania treści ekologicznych, in: Filozoficzne wizje i modele świata, (ed.): W. Kamiński, S. Konstańczak, Słupsk 2002.

Ciszek M., Jozefa M. Dolęgi koncepcja ekofilozofii systemowej, „Doctrina”. Międzynarodowy Przegląd Humanistyczny, nr 2, 2005.

CiszeK M., Wokót wybranych idei chrześcijańskiego humanizmu ekologicznego, in: Veritas sed doctrina multiplex. Ksiega pamiątkowa ku czci prof dr hab. Józefa Jaronia, (ed.): W. Słomski, M. CiszeK, Siedlce 2003.

DoŁĘGA J.M., Ekologia w teologii i filozofii chrześcijańskiej, in: Wprowadzenie do filozoficznych problemów ekologii. Wprowadzenie do filozoficznych problemów ekologii, (ed.): A. Papuziński, Bydgoszcz 1999.

GRZESICA J., Ochrona naturalnego środowiska. Problem teologiczno - moralny, Katowice 1983.

LORDA J.L., Moralność - sztuka życia, Warszawa - Ząbki 1999.

ŁUKomsKi J., Podstawy chrześcijańskiej etyki środowiska naturalnego, in: Ochrona środowiska w filozofii i teologii, (ed.): J.M. Dołęga, J.W. Czartoszewski, Warszawa 1999.

Łukomski J., Próba zbudowania chrześcijańskiej etyki środowiska naturalnego, Kielce 2000.

Ślipko T., Zwoliński A., Rozdroża ekologii, Kraków 1999.

Tyвurski W., Glówne kierunki i zasady etyki środowiskowej, in: Wprowadzenie do filozoficznych problemów ekologii, (ed.): A. Papuziński, Bydgoszcz 1999. 


\title{
Idea teocentryzmu w katolickiej etyce środowiskowej
}

\author{
STRESZCZENIE
}

W artykule tym starałem się przedstawić zarys autorskiej koncepcji katolickiej wersji etyki środowiskowej w paradygmacie teocentrycznym. Uważam przy tym, że ekoetyka uprawiana w tym modelu, może okazać się swoistą trzecią drogą pozwalającą na uniknięcie kontrowersji jakie stały się udziałem antagonistycznych względem siebie obozów zwolenników biocentryzmu i antropocentryzmu. Uznałem więc, iż stanowi ona efektywny sposób uprawiania etyki ekologicznej.

W dużym skrócie teocentryczna odmiana etyki środowiskowej nakazuje rozpatrywać wszelkie relacje między działaniami moralnymi człowieka a przyrodą, w odniesieniu do Boga, jako Stwórcy przyrody i kosmosu. Przyroda posiada wartość ze względu na Boga stanowiącego summum bonum w chrześcijańskiej etyce - który ją stworzył i nadal utrzymuje w istnieniu. Wartością autoteliczną w mojej koncepcji etyki środowiska naturalnego jest człowiek, aczkolwiek ta szczególna pozycja nie zwalnia go z odpowiedzialności za los środowiska. Człowiek jako istota wyjątkowa powinien pełnić rolę dobrego strażnika, gospodarza i opiekuna świata przyrody, którą otrzymał w darze od Stwórcy. Natomiast niszcząc przyrodę sprzeciwia się Bogu, a więc grzeszy i czyni zło.

Na podstawie moich rozważań ostatecznie przyjmuję, iż człowiek jako byt stanowiący „koronę stworzenia”, jest szczególnie odpowiedzialny za cały otaczający go świat przyrody, któremu należy się szacunek, gdyż jest on darem Stwórcy dla człowieka i powinien zostać zachowany jako dziedzictwo dla przyszłych pokoleń, naturalnie przy współudziale edukacji. 